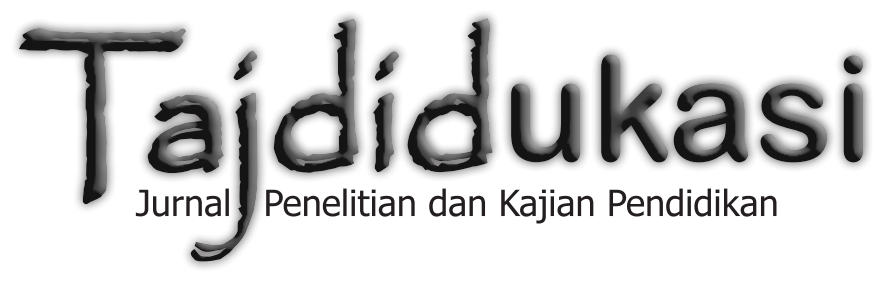




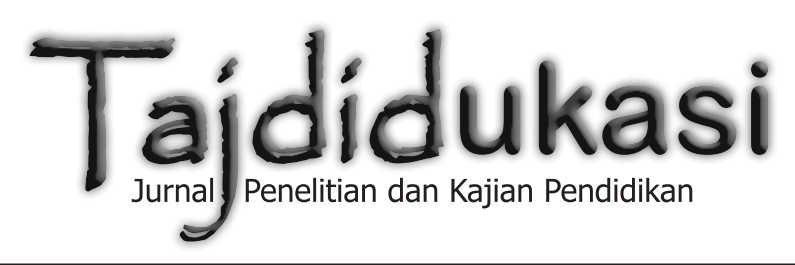

Volume VIII, No. 2, Juli 2018

ISSN: 1979-6943

Tajdidukasi: Jurnal Penelitian dan Kajian Pendidikan merupakan jurnal Penelitian dan Kajian Pendidikan yang berisi Penelitian Tindakan Kelas (PTK) dan Penelitian Tindakan Sekolah (PTS) serta Kajian Pendidikan interdisipliner di Perguruan Tinggi yang diterbitkan Majelis Pendidikan Dasar dan Menengah Pimpinan Wilayah Muhammadiyah Daerah Istimewa Yogyakarta. Artikel hasil PTK dan PTS serta kajian pemikiran pendidikan ditulis oleh para Guru dan Kepala Sekolah serta Dosen dalam mengujicobakan metode dan strategi pembelajaran untuk meningkatkan kualitas pendidikan baik SD/MI, SMP/MTs dan SMA/MA/SMK serta Perguruan Tinggi. Artikel PTK dan PTS fokus pada mata pelajaran di sekolah/madrasah, seperti Ilmu Pengetahuan Alam (IPA), Imu Pengetahuan Sosial (IPS), Matematika, Fisika, Kimia, bahkan teknik, seperti Teknik Mesin, Elektro, Informatika dan lain sebagainya. Sementara itu, artikel Kajian Pendidikan merupakan penelitian interdisipliner dan multidisipliner yang dilakukan Dosen di Perguruan Tinggi terhadap khasanah keIslaman.

Tajdidukasi: Jurnal Penelitian dan Kajian Pendidikan adalah jurnal terbuka yang versi softfile-nya bisa dibaca dan diakses secara gratis, sementara versi print out/ hardcopy dapat diperoleh dengan menghubungi distributor di alamat serial tajdidukasi.ac.id. Sof-file keseluruhan artikel yang diterbitkan dapat diakses melalui Tajdidukasi Open Access Juornal di www.dikdasmenpwmdiy.or.id

Pimpinan Editor
Suyadi, Universitas Ahmad Dahlan (UAD) Yogyakarta, Indonesia

Anggota Editor

Arif Budi Raharjo, Universitas Muhammadiyah Yogyakarta (UMY), Indonesia

Achmad Muhammad, UIN Sunan Kalijaga Yogyakarta, Indonesia

Hendro Widodo, Universitas Ahmad Dahlan (UAD) Yogyakarta

Mundzirin Yusuf, UIN Sunan Kalijaga Yogyakarta, Indonesia

Sumedi, UIN Sunan Kalijaga Yogyakarta, Indonesia

Sukamto, Universitas Muhammadiyah Yogyakarta (UMY), Indonesia

Sumarsono, UIN Sunan Kalijaga Yogyakarta Indonesia

Sarjilah (Lembaga Penjaminan Mutu Pendidikan) Yogyakarta

Fathur Rahman, M.Si., Universitas Negeri Yogyakarta (UNY) Indonesia

\section{Editor Pelaksana}

Suryanto, Universitas Muhammadiyah Yogyakarta (UMY), Indonesia

Suyatno, Universitas Ahmad Dahlan (UAD) Yogyakarta

Farid Setiawan, Universitas Ahmad Dahlan (UAD) Yogyakarta

Alamat Redaksi:

Kantor Majelis Pendidikan Dasar dan Menengah Pimpinan

Wilayah Muhammadiyah D.I. Yogyakarta

J1. Gedongkuning No. 130B Yogyakarta

Kode Pos : 55171

Telephone : (0274) 377078

Facsimile : (0274) 371718

Website : www.dikdasmenpwmdiy.or.id

E-Mail : tajdidukasi@dikdasmenpwmdiy.or.id 


\title{
PENGARUH MODEL PEMBELAJARAN THINK PAIR SHARE TERHADAP MOTIVASI DAN HASIL BELAJAR PELAJARAN EKONOMI
}

\author{
Rahayu Saraswati \\ Muhammadiyah Boarding School Prambanan Sleman Yogyakarta \\ Email: saras_77@ymail.com
}

\begin{abstract}
Abstraksi
Penelitian ini bertujuan untuk meningkatkan motivasi dan hasil santri dalam belajar ekonomi dengan menerapkan model pembelajaran Think Pair Share (TPS). Teknik pengumpulan data menggunakan observasi dan kuesioner sebanyak 29 santri putra kelas 11 IPS. Hasil penelitian dapat disimpulkan bahwa metode pembelajaran kooperatif Think Pair Share (TPS) dapat meningkatkan motivasi belajar ekonomi santri dibuktikan dengan adanya peningkatan prosentase dari siklus I sebesar 49,78\% menjadi $78,77 \%$ pada siklus II kenaikan tersebut karenakan santri tekun menghadapi tugas, lebih aktif dalam pemecahan masalah, minat terhadap pelajaran tinggi, aktif bertanya dan berargumen, dan ada keinginan berhasil. Dari evaluasi hasil belajar siklus 1 rata-rata nilai berada pada range $71-73$ sebesar $28 \%$, pada siklus kedua terjadi peningkatan menjadi 74-80 sebesar 41\%. Hasil ini menunjukkan bahwa pembelajaran menggunakan Metode Pembelajaran Kooperatif Teknik TPS menjadikan kegiatan belajar mengajar menjadi lebih menyenangkan.
\end{abstract}

Kata kunci: think pair share, motivasi belajar, hasil belajar

\section{A. PENDAHULUAN}

Pendidikan saat ini merupakan kebutuhan dasar yang harus dipenuhi oleh setiap anak usia sekolah. Pendidikan yang baik adalah pendidikan yang tidak hanya mempersiapkan para santrinya untuk sesuatu profesi atau jabatan, tetapi untuk menyelesaikan masalah-masalah yang dihadapinya dalam kehidupan sehari-hari (Trianto, 2010). Proses pembelajaran disekolahsekolah mengacu pada Permendiknas RI No.41 tahun 2007 tentang standar proses. Kegiatan pembelajaran dalam peraturan tersebut terdiri dari pendahuluan, inti dan penutup.

Realitas empiris guru belum mampu memaksimalkan potensi peserta didik dalam belajar secara mandiri dalam proses belajar mengajar di Muhammdiyah Boarding School (MBS) Prambanan Yogyakarta. Guru kurang memfasilitasi para santri dalam proses kegiatan belajar mengajar secara kooperatif, sehingga guru menjadi tumpuan tunggal dalam proses belajar mengajar. Implikasi pada hasil pembelajaran yang rendah yaitu 
nilai ulangan harian dan Penilaian Tengah Semester (PTS) belum memenuhi standar Kriteria Ketuntasan Minimal (KKM).

Beberapa kendala yang terjadi dalam Kegiatan Belajar Mengajar (KBM) di MBS Yogyakarta menunjukkan adanya masalah saat proses pembelajaran berlangsung. Salah satu masalah yang dihadapi dunia pendidikan Indonesia saat ini adalah lemahnya proses pembelajaran. Model pembelajaran yang hanya menekankan pada pemikiran produktif, hafalan dan mencari satu jawaban yang benar terhadap soal-soal yang diberikan, sudah saatnya untuk ditinggalkan dan kini beralih ke proses berpikir kreatif dan inovatif (Sanjaya, 2010a).

Think Pair Share (TPS) merupakan teknik pembelajaran dalam pembelajran kooperatif yang pertama kali dikembangkan oleh Frank Lyman tahun 1981. Think Pair Share merupakan pembelajaran kooperatif dengan menggunkan tahap-tahap pembelajaran, yakni tahap berpikir, tahap berpasangan, dan tahap berbagi. Metode pembelajaran TPS memberi kesempatan para santri untuk belajar mandiri dan berbagi dengan santri yang lain (Suyadi, 2013). Keunggulan lain dari metode ini adalah optimalisasi partisipasi santri. Metode ini memberi kesempatan lebih banyak kepada setiap santri untuk dikenali dan menunjukkan partisipasi mereka kepada santri yang lain dengan tujuan sinergitas peningkatan pada motivasi belajar dan hasil belajar.
Hasil penelitian menunjukkan model pembelajaran think pair sare dapat meningkatkan motivasi dan hasil belajar (Chatarina, 2006), penelitian tetang hasil belajar dan pembelajaran kooperatif tipe think pair share (TPS) dengan metode analisis tematik dan analisis deskriptif menunjukkan dapat meningkatkan hasil belajar IPS kelas IV sekolah dasar (Jasdilla, Kuswendi, \& Ramdhani, 2017), dan penelitian yang lain juga menunjukkan adanya peningkatan hasil belajar siswa kelas III SDN Ngulanan 2 Bojonegoro (Thayyibandhi \& Sudianto, 2014).

Penelitian tentang pengaruh penggunaan cooperative learning tipe think pair share (PTS) terhadap hasil belajar kewirausahaan siswa kelas $\mathrm{x}$ semester genap SMK Kartikatama 1 Metro T.P 2015/2016 dengan hasil penggunaan cooperative learning tipe think pair share (TPS) dapat meningkatkan hasil belajar kewirausahaan siswa kelas X AK1 semester genap (Safitri \& Ningrum, 2016). Penelitian pengaruh model pembelajaran think pair share (TPS) terhadap hasil belajar IPA dengna alat analisis Quasi eksperimen dengan rancangan posttes-only control group design dengan hasil berupa model pembelajaran TPS dapat digunkan sebagai alternatif model pembelajaran untuk meingkatkan hasil belajar IPA (Surayya, Subagia, \& Tika, 2014). Penelitan penggunaan model pembelajaran kooperatif tipe think pair share berbasis media komputasi pada materi struktur atom kelas X MAN Biau hasil belajar 
kimia siswa yang diberi perlakuan dengan menggunakan model pembelajaran kooperatif tipe think pair share berbasis media komputasi lebih baik dibandingkan dengan yang tidak diberi perlakuan pada materi struktur atom (Rewa \& Said, 2014).

Model pembelajaran think pair share terdiri dari tiga tahap, yaitu tahap thinking (berpikir), pairing (berpasangan), dan sharing (berbagi). Tahap think, siswa harus berpikir sendiri tentang jawaban atas permasalahan yang diberikan oleh guru. Berpikir merupakan proses kognitif, yaitu suatu aktivitas mental untuk memperoleh pengetahuan. Ketika harus berpikir, maka akan ada dialog dengan diri sendiri. Tahap pair, siswa akan berpasangan untuk mendiskusikan hasil berpikir mereka sebelumnya. Dalam berdiskusi diperlukan beberapa keterampilan berpikir, antara lain: mengenal masalah; menemukan cara-cara yang dapat dipakai untuk menangani masalah-masalah tersebut; mengumpulkan dan menyusun informasi yang diperlukan; memahami dan menggunakan bahasa yang tepat dan jelas; menganalisis data; dan menarik kesimpulan (Surayya et al., 2014). Think pair share dengan media kartu berpasangan mempengaruhi motivasi belajar dan meningkatkan hasil belajar, maka semakin aktif dalam berfikir dan berbagi maka akan memperkuat model pembelajaran sehingga motivasi belajar santri dan secara otomatis ada peningkatan hasil belajar santri.

\section{B. METODE PENELITIAN}

Penelitian ini mengambil lokasi di Pondok Pesantren Muhammadiyah Boarding School kelas XI IPS. Penelitian ini menggunakan model penelitian tindakan dari Kemmis dan Teggart (Suharsimi, 2017).

Gambar 1. Penelitian Tindakan Kelas

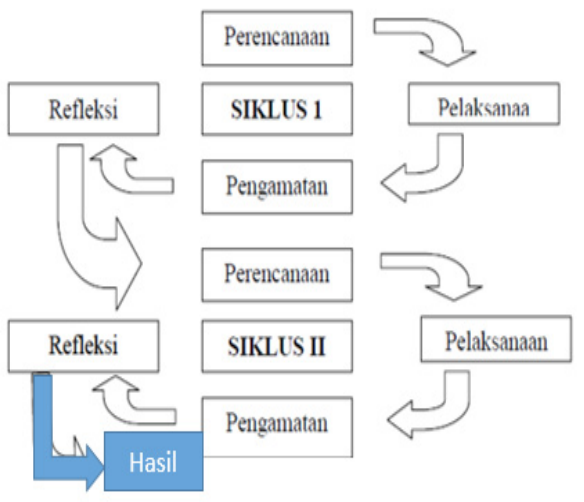

\section{a. Perencanaan Tindakan}

Pada proses perencanaan peneliti menyiapkan segala sesuatu yang dibutuhkan saat pelaksanaan siklus 1 meliputi :

1. Membuat RPP sesuai dengan metode pembelajaran

2. Membuat Lemar Penilaian

3. Membuat Lembar Observasi Santri

4. Membuat Kuesioner

5. Menyiapkan media kertas berpasangan yaitu kumpulan materi beserta soal.

\section{b. Pelaksanaan Tindakan}

Pelaksanaan siklus dibagi menjadi 2 yaitu: 


\section{Siklus 1}

a. Perencanaan

\section{Pendahuluan}

a. Guru membuka dan memberi motivasi,kemudian menyampaikan SKKD

b. Memberikan penjelasan dengan metode TPS

c. Guru menyampaikan materi atau tema yang akan dibahas

\section{Kegiatan Inti}

a. Masing-masing santri memiliki kartu yang berisi soal untuk dipikirkan (think) jawaban sementara secara mandiri

b. Santri mencari pasangan kartu sesuai dengan topik yang dibahas dan berpasangan (pair) mendiskusikan sesuai dengan topik.

c. Santri mempresentasikan (share) hasil pekerjaan kelompok kemudian guru mengoreksi hasil pekerjaan yang dipresentasikan.

\section{Kegiatan akhir}

a. Guru dan santri menyimpulkan materi yang sudah dibahas,

b. Guru menyampikan materi untuk pertemuan selanjutnya,

c. Guru menutup dengan doa diakhiri dengan salam.

\section{c. Pengamatan}

Pengamatan dilakukan saat proses pembelajaran berlangsung. Peneliti melakukan pengamatan kegiatan santri satu per satu dan pencatatan proses pembelajaran serta pemberian skor pada lembar observasi untuk mengetahui kemunculan motivasi siswa. Peneliti juga mengamati kekurangan dari proses pembelajaran yaitu kurangnya kehadiran santri pada saat proses KM berlangsung untuk digunakan sebagai refleksi pembelajaran siklus ke 2 .

\section{d. Refleksi}

Proses refleksi dilakukan dari data yang diperoleh selama observasi dianalisis untuk mengevaluasi pelaksanaan pembelajaran yang kemudian nantinya dapat diketahui permasalahan yang muncul selama proses pembelajaran. Selanjutnya disusun pemecahan atas masalah tersebut. Hasil dari tahap ini kemudian digunakan oleh peneliti sebagai dasar bagi tindakan selanjutnya.

\section{Siklus 2}

Pada siklus 2 merupakan tindakan perbaikan dari siklus 1 yang masih belum berhasil. Secara umum, kegiatan pada siklus 2 sama dengan pembelajaran siklus 1 , hanya saja dilakukan lebih cermat dan memperhatikan hal-hal yang masih belum tercapai.

Teknik analisis data dalam penelitian berupa analisis deskriptif. Data yang diperoleh dari kuesioner kemudan dihitung skor motivasinya

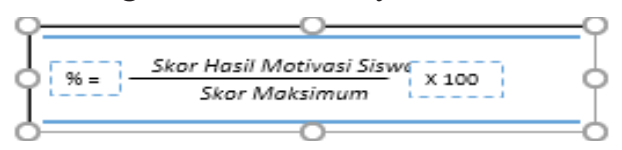

a. Uji Validitas

Uji validitas digunakan untuk men- 
dapatkan kevalitan data pada kuesioner motivasi dalam pembelajaran ekonomi yang akan diberikan kepada santri. Perhitungan uji validitas menggunakan program SPSS.

b. Uji Realibilitas

instrumen yang dipercaya akan menghasilkan data yang dapat dipercaya juga. Hasil uji realibilitas memanfaatkan program SPSS.

\section{Hasil dan Pembahasan}

\section{Hasil}

Penelitian dilakukan di pondok pesantren MBS Prambanan Sleman jumlah populasi santri kelas 11 IPS putra sebanyak 57 yang menjadi sampel penelitian sebanyak 29 santri. Pelajaran ekonomi memiliki 5 jam pelajaran dalam seminggu.

\section{Pra penelitian tindakan Kelas}

a. Observasi dilaksankan pada tanggal 1 Februari 2018, pada observasi awal santri kurang bersemangat dalam mengikuti pelajaran ekonomi karena materi ekonomi akuntansi dirasa sulit.

b. Perencanaan Rancangan Tindakan

Penelitian ini dilakukan 2 siklus, santri dibagi menjadi 11 kelompok setiap kelompok terdiri dari 2 hingga 3 santri (total 29 santri), 3 observer. Observer melakukan pengamatan motivassi santri mengerjakan soal hingga selesai, bertanya ketika kurang paham, meemperhati- kan materi yang diberikan oleh guru, tidak menunggu jawaban kepada teman, memberikan argumen atas hasil pekerjaannya, segera mengerjakan dan mengumpulkan tugasyang diberikan, bersemangat dan aktif menjawab setiap pertanyaa, dan antusias menggunkan metode pembelajaran yang baru.

\section{Siklus 1}

a. Perencanaan Tindakan

Pada tahap perencanaan dilaksanakan pada tanggal 12 Februari 2018, kegiatan yang dilakukan membuat RPP, membuat media kartu dan name tag, menyusun lemar observasi, membuat angket, dan membuat daftar kelompok.

b. Pelaksanaan Tindakan

Pelaksanan tindakan dilakukan pada 14 Feruari 2018 dengan langkahlangkah; guru membuka dengan salam dan doa kemudian menyampaikan SK KD dan materi, guru membagikan kartu pasangan secara acak kepada santri, masing-masing santri mempunyai kartu untuk dipikirkan (think) jawaban sementara secara mandiri, kemudian santri mencari pasangan kartu yang sama, siswa berpasangan (Pair) mendiskusikan soal yang ada didalam kartu tersebut. Setelah berdikusi santri mempresentasikan (share) hasil dikusi dihadapan santri lain. Guru memberikan penguatan dengan tanyajawab secara lisan dan memberi kesimpulan.

Pengamatan dilakukan bersamaan dengan tindakan, observer mengamati 
mteode PTS mampu diterima dengan baik oleh santri dan mengamati motivasi belajar santri. Setelah diobservasi ternyata pada siklus 1 pada tahapan pairing dalam pembelajaran yang diharapkan memicu santri berdikusi ternyata belum berjalan optimal. Hasil penilaian motivasi belajar menunjukkan masih ada beberapa indikator motivasi belajar ekonomi akuntansi masih di bawah kriteria keberhasilan minimal. Berdasarkan hasil analisis langkah selanjutnya guru memotivasi santri agar lebih aktif dalam penerapan metode PTS, sehigga santri yakin, mantap, percaya diri dalam mengutarakan pendapat saat diskusi.

\section{c. Pengamatan}

Berdasarkan motivasi belajar pada siklus 1 diukur melali lembbar observasi menunjukkan bahwa motivasi belajar ekonomi kelas 11 IPS masih dibawah kriteria keberhasilan minimal.

\section{d. Refleksi}

Berdasarkan data dapat diketahui bahwa hasil siklus 1 sangat tidak optimal jika dibandingkan observasi awal. Perlu menjadi bahan refleksi yaitu tahapan berkelompok tidak sesuai dengan rencana sehingga belum berjalan optimal. Koordinasi antara santri dan guru perlu ditingkatkan, penjelasan mengenai manfaat metode PTS belum diterima dengan baik.

\section{Siklus 2}

\section{a. Perencanaan Tindakan}

Pelaksanaan siklus 2 ini dilaksanakan pada tanggal 28 Febuari 2018, hasil yang diperoleh pada siklus1 menunjuk- kan nilai dibawah minimal yaitu $75 \%$, hal ini menunjukkan bahwa motivasi santri masih dibawah nilai yang diharapkan sehingga perlu dilakukan siklus 2. Tidak berbeda dengan siklus 1 beberapa perlengkapan yang disiapkan RPP, lembar observasi, kuesioner, materi dan soal latihan.

\section{b. Pelaksanaan Tindakan}

Guru membuka dengan salam dan doa, santri diberi kertas pasangan yang sudah diberi nama kelompok dan dibagi materi dan soal kemudian mencari teman pasangannya. Guru menyampaikan materi jurnal umum. Masing-masing santri mempunyai kertas soal untuk dipikirkan (think), santri berpassangan sesuai dengan nama kelompok pasangan dan berdiskusi (pair), santri mempresentasikan (share) hasil kelompok. Guru membahas materi dan menyimpulkan diakhiri dengan mengisi angket.

Berdasarkan data yang ada jika dilihat tiap indikator motivasi belajar mencapai kriteria minimal yang telah ditetapkan yaitu sebesar $75 \%$. Melihat keseluruhan hasil telah melampaui kriteria minimal sebesar $78,47 \%$.

\section{Pembahasan}

Penelitian yang telah dijalankan meliputi perencanaan, tindakan, pengamatan, dan refleksi. Pelaksanaan pembelajaran dengan Metode Pembelajaran Kooperatif teknik Think Pair Share (TPS) berbantuan media kertas berkelompok baik pada siklus 1 maupun siklus 2 siswa menunjukan adanya aktivitas berikut terlampir perbandingan 
hasil motivasi belajar ekonomi berdasarkan observasi.

Gambar 2. Motivasi Belajar Ekonomi Berdasarkan Observasi

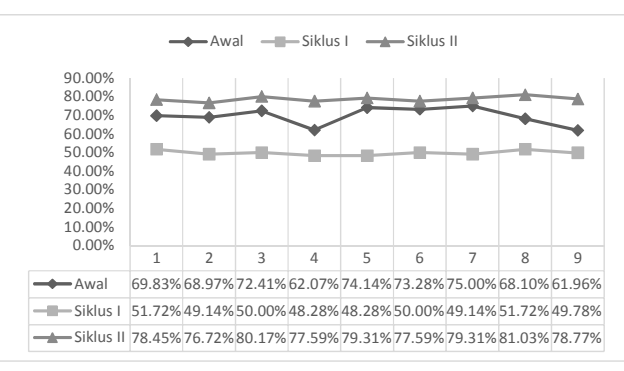

Sumber: data diolah

Keterangan:

1: Tekun menghadapi tugas.

2: Ulet menghadapi kesulitan.

3: Memiliki minat terhadap pelajaran.

4: Lebih senang bekerja mandiri.

5: Dapat mempertahankan pendapat.

6: Senang mencari dan memecahkan masalah soal-soal.

7: Memiliki hasrat dan keinginan berhasil.

8: Adanya kegiatan yang menarik dalam belajar

Berdasarkan data tersebut dapat dilihat adanya peningkatan motivasi belajar ekonomi untuk santri kelas 11 IPS 1 dengan penerapan metode pembelajaran kooperatif teknik think pair share (TPS). Peningkatan motivasi belajar tersebut yaitu dari awal sebesar $61,96 \%$ terjadi penurunan pada siklus 1 menjadi $49,78 \%$ turun sebesar $12,18 \%$ kemudian terjadi peningkatan pada siklus 2 sebesar 78,77\% naik sebesar 28,99\%. Pemberian skor mempermudah peneliti dalam menginterprestasikan hasil. Berdasarkan data yang telah ditampilkan di atas, yaitu data observasi maupun kuisioner dapat dilanjutkan ke tahap berikutnya yaitu penarikan kesimpulan.

Grafik 1. Hasil Kuesioner Motivasi Ekonomi

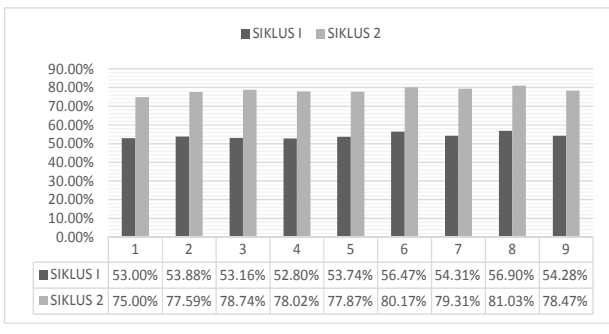

Sumber: data diolah

Berdasarkan hasil kuesioner motivasi belajar ekonomi kelas 11 IPS 1 ditunjukkan hasil peningkatan dari siklus I ke siklus II dari 54,28\% menjadi $7847 \%$. Hal ini menunjukkan bahwa motivasi belajar santri mengalami peningkatan.

a. Indikator tekun menghadapi tugas

Peningkatan skor Motivasi Belajar Ekonomi santri juga ditunjukkan dari data di mana terjadi peningkatan sebesar $26,73 \%$ dari siklus 1 ke siklus 2 telah tercapai ketentuan minimal $75 \%$. Begitu pula untuk kuesioner mengalami peningkatan kenaikan sebesar 22\%. Dengan tekun menghadapi tugas santri. Begitu juga untuk kuesioner moivasi belajar santri mengalami peningkatan. Hal ini sejalan dengan pendapat (Sanjaya, 2010a) bahwa metode pembelajaran kooperatif dapat memberdayakan siswa untuk lebih bertanggung jawab dalam pembelajaran. 


\section{b. Indikator ulet menghadapi kesu-} litan

Pada siklus I menunjukkan penurunan dalam ulet menghadapi kesulitan sebesar $20,42 \%$. Sedangkan pada siklus II indikator ulet menghadapi kesulitan mengalami peningkatan sebesar $27,58 \%$. Peningkatan ini terjadi karena siswa sudah mulai terbiasa dan berani bertanya kepada guru untuk mencari pemecahan masalah dengan bertanya kepada guru sehingga keuletan siswa meningkat.

\section{c. Indikator memiliki minat terha- dap pelajaran}

Terjadi peningkatan dalam menggunakan teknik Think Pair Share sebesar $30,17 \%$.Selaras dengan data tersebut, pada angket terjadi peningkatan skor sebesar 7,83\%. Penerapan pembelajaran teknik Think Pair Share (TPS) berbantuan media kartu berpasangan ini siswa lebih fokus untuk memperhatikan penjelasan guru dan menimbulkan komunikasi dua arah antara siswa dengan guru yang tampak pada saat penyampaian materi guru memberikan pertanyaan, hampir semua siswa menjawabnya secara bersamaan. Dengan demikian siswa menjadi lebih cepat paham mengenai materi yang disampaikan oleh guru (Sayuga, 2014).

\section{d. Indikator lebih senang bekerja mandiri}

Berdasarkan hasil siklus 1 ke siklus 2 mengalami peningkatan sebesar $29,31 \%$ sedangkan data kuesioner menunjukkan peningkatan sebesar
$25,22 \%$. Siklus mengalami peningkatan yang dikarenakan santri sudah mulai menyesuaikan dengan pembelajaran yang dilaksanakan sehingga mereka sudah mempersiapkan diri khususnya untuk mengerjakan tugas yang diberikan. Sejalan dengan (Sanjaya, 2010b) mengemukakan dalam pembelajaran secara mandiri dapat melatih tanggungjawab siswa dalam belajar. Adanya tanggungjawab santri dalam belajar, kemandirian siswa dalam belajar akan dapat ditingkatkan (Johnson, 2007).

\section{e. Indikator dapat mempertahan- kan pendapatnya}

Peningkatan dari siklus 1 ke siklus 2 sebesar 31,01\% dan data kuesioner terjadi peningkatan sebesar $24,13 \%$. Berdasarkan data yang diperoleh dapat terlihat bahwa sebagian siswa memahami dan mampu menjelaskan argumen atau alasan dari hasil pekerjaan kelompoknya.Sesuai dengan pendapat (Sanjaya, 2010b) bahwa pembelajaran kooperatif melatih siswa untuk dapat mampu berpartisipasi aktif dan berkomunikasi dalam menyatakan ketidaksetujuan atau menyanggah pendapat orang lain. Dari sinilah siswalebih mampu mempertahankan pendapatnya.

\section{f. Indikator senang mencari dan memecahkan masalah soal-soal.}

Terjadi peningkatan motivasi belajar ekonomi siklus 1 ke siklus 2 yaitu $50,00 \%$ selaras dengan data observasi, data kuesioner juga menunjukkan adanya peningkatan sebesar 23,70 . Selain itu (Ida \& Suarni, 2016) mengung- 
kapkan bahwa pembelajaran ini dapat mengembangkan kemampuan siswa untuk menguji ide dan pemahamannya sendiri, siswa dapat berpraktik memecahkan masalah tanpa takut membuat kesalahan karena keputusan merupakan tanggung jawab kelompok.

\section{g. Indikator adanya hasrat dan keinginan berhasil}

Kenaiakn dari siklus 1 ke siklus 2 sebesar 30,17\%. Sedangkan untuk data kuesioner mengalami peningkatan sebesar $25 \%$. Melalui pembelajaran ini siswa memiliki motivasi untuk berhasil. Hasrat dan keinginan berhasil juga didapatkan dari dorongan teman seperti diungkapkan (Sri \& Harini, 2014) sama halnya dengan penelitian (Amelia, 2016) bahwa komponen pembelajaran kooperatif yaitu interaksi promotif suatu interaksi dalam kelompok dimana setiap kelompok anggota saling mendorong dan membantu anggota lain salam mencapai tujuan. Keinginan berhasil terlihat adanya keaktifan setiap kelompok hal ini menyebabkan terciptanya peningkatan prestasi belajar, semakin aktif maka semakin tinggi prestasi belajar (Dimyati \& Mudjiono, 1999).

\section{h. Indikator adanya kegiatan yang menarik dalam belajar}

Terjadi peningkatan skor sebesar pada siklus 1 ke siklus 2 sebesar 29,31\%. Selaras dengan data observasi, data kuesioner juga menunjukkan adanya peningkatan skor sebesar $24,13 \%$. Berdasarkan data tersebut sebagian besar siswa tertarik dengan pem- belajaran yang dilakukan menggunakan media kartu berpasangan karena siswa lebih aktif dan merasa tertantang untuk menyelesaikan kasus soal yang ada di dalam kerts, disisi lain siswa berani mengutarakan jawabannya dan menkonfirmasikan pertanyaan-petanyaan dari teman-temannya.

3. Karakteristik mata pelajaran dengan penerapan model pembelajaran Think Pair Share

Pembelajaran yang peneliti terapkan merupakan mata pelajaran Ekonomi dengan materi Akuntansi. Metode Think Pair Share ini dapat diterapakan dengan karakteristik sebagai berikut:

1. Materi yang diajarkan merupakan materi hitungan,

2. Materi memiliki jawaban yang sudah dipastikan jawabannya (misal dalam menentukan debit dan kredit, atau jumlah barang dan jumlah uang yang harus dihitung),

3. Materi berkelanjutan (antara bab sebelumnya dan sesudahnya ada keterkaitan/keberlangsungan),

Nilai untuk siklus 1 terlihat bahwa $34 \%$ santri tidak menikuti KBM sehingga tidak memiliki nilai (0) sedangkan nilai yang paling tinggi prosentasenya antara range $71-73$ sebesar $28 \%$ kemudian pada range $74-76$ sebesar $24 \%$ dan nilai $68-70$ sebesar $14 \%$. 
Tabel 1. Nilai Hasil Evaluasi siklus 1

\begin{tabular}{|c|c|c|}
\hline Nilai & frekuensi & $\%$ \\
\hline 0 & 10 & $34 \%$ \\
\hline $68-70$ & 4 & $14 \%$ \\
\hline $71-73$ & 8 & $28 \%$ \\
\hline $74-76$ & 7 & $24 \%$ \\
\hline
\end{tabular}

Sumber: Data diolah

Pada siklus ke 2 nilai tertingggi ada 2 santri pada range $86-90$ sebesar 7\%, untuk range $81-85$ sebesar $21 \%$, pada range $76-80$ sebesar $41 \%$ merupakan prosentase tertinggi dan yang terahir pada nilai paling rendah 71-75 sebesar 31\% sesuai dengan penelitian (Wardana \& Edoh, 2017) adanya peningkatan hasil belajar setalah memiliki pemahaman dalam metode PTS.

Tabel 2. Nilai Hasil Evaluasi siklus 2

\begin{tabular}{|c|c|c|}
\hline Nilai & frekuensi & $\%$ \\
\hline $71-75$ & 9 & $31 \%$ \\
\hline $76-80$ & 12 & $41 \%$ \\
\hline $81-85$ & 6 & $21 \%$ \\
\hline $86-90$ & 2 & $7 \%$ \\
\hline
\end{tabular}

Sumber: data diolah

\section{Kesimpulan}

Berdasarkan hasil penelitian dan pembahasan maka dapat disimpulkan:

1. Penerapan Metode Pembelajaran Kooperatif Teknik Think Pair Share (TPS) berbantuan media Kertas Berkelompok dapat meningkatkan Motivasi Belajar Ekonomi siswa kelas XI IPS 1 di MBS Yogyakarta yang dibuktikan dengan adanya peningkatan persentase skor Motivasi Belajar Ekonomi yang diambil melalui observasi terjadi penurunan sebesar $12,18 \%$ dikarenakan ada 8 (delapan) santri yang tidak berangkat menyebabkan terjadi penurunan serta langkah-langkah pembelajaran yang kurang dipersiapkan dengan maksimal serta manajemen kelas kurang berjalan lancar.

2. Berdasarkan hasil kuesioner yang didistribusikan kepada santri dapat disimpulkan pula bahwa terjadi peningkatan skor Motivasi Belajar Ekonomi sebesar 24,19\%. Hal ini mengindikasikan bahwa motivasi setiap santri untuk metode pembelajar TPS meningkat sehingga santri dapat mengaktualisasi diri dalam pembelajaran ekonomi.

\section{DAFTAR PUSTAKA}

Amelia, K. R. (2016). Using think-pairshare-strategy to improve vocabulary and reading comprehension achievements of eighth grade students. Journal of English Literacy Education, 3(2), 148-156.

Chatarina, A. (2006). Psikologi Belajar. Semarang: UPT UNNES Pres.

Dimyati, \& Mudjiono. (1999). Belajar dan Pembelajaran. Jakarta: PT Rinek Cipa dan Departemen Pendidikan dan Kebudayaan.

Ida, F., \& Suarni. (2016). Model Pembelajaran Kooperatif Dan Impli- 
kasinya Pada Pemahaman Belajar Sains Di SD/MI (Studi PTK di Kelas III MIN 3 WatesLiwa Lampung Barat). Terampil : Jurnal Pendidikan Dan Pembelajaran Dasar, 3, 301-322.

Jasdilla, L., Kuswendi, U., \& Ramdhani, S. (2017). Hasil Belajar Dan Pembelajaran Kooperatif Tipe Think Pair Share (Tps). JPI (Jurnal Pendidikan Indonesia), 6(1), 96-105. https://doi.org/10.23887/ jpi-undiksha.v6i1.9253

Johnson, E. . (2007). Contxtual Teaching and Larning: Mejadikan Kegiatan Belajar Mengajar Mengasyikan dan Bermakna. Bandung: Mizan Learning Center.

Rewa, Z. S., \& Said, I. (2014). Penggunaan Model Pembelajaran Kooperatif Tipe Think Pair Share Berbasis Media Komputasi Pada Materi Struktur Atom Kelas X MAN Biau, 3(August), 150-157.

Safitri, K. L., \& Ningrum. (2016). Pengaruh Penggunaan Cooperative Learning Tipe Think-Pair-Share (TPS) Terhadap Hasil Belajar Kewirausahaan Siswa Kelas X Semester Genap SMK Kartikatama 1 Metro. Jurnal Pendidikan Ekonomi, 4(1), 21-34. Retrieved from http://ojs.fkip.ummetro.ac.id

Sanjaya, W. (2010a). Penelitian Tindakan Kelas. Jakarta: Kencana Prenada Media Group.

Sanjaya, W. (2010b). Strategi Pembela- jaran Berorientasi Standar Proses Pendidikan. Jakarta: Prenada Media Group.

Sayuga, M. R. (2014). Penerapanmetode Pembelajaran Kooperatif Teknik Think Pair Share (Tps) Berbantuanmedia Kartu Berpasangan Untukmeningkatkanmotivasi Belajar Akuntansi Siswakelas Xi Ips 3Man Yogyakarta Ii Tahun Ajaran 2013/2014.

Sri, R. R., \& Harini, E. (2014). Pengaruh Pembelajaran Kooperatif Tipe Think Pair Share ( TPS ) Terhadap Prestasi Belajar Matematika Ditinjau Dari Motivasi Siswa Kelas X SMA NEGERI 1 Pengasih Kulon Progo Tahun Pelajaran 2013 / 2014, 2(3), 249-256.

Suharsimi, A. (2017). Pengembangan instrumen penelitian dan penilaian program. yogyakarta: pustaka pelajar.

Surayya, L., Subagia, I. W., \& Tika, I. N. (2014). Pengaruh Model Pembelajaran Think Pair Share Terhadap Hasil Belajar IPA Ditinjau Dari Keterampilan Berpikir Kritis Siswa. E-Journal Program Pascasarjana Universitas Pendidikan Ganesha, 4, 1-11. Retrieved from https://media.neliti.com/ media/publications/122468-IDpengaruh-model-pembelajaranthink-pair-s.pdf

Suyadi. (2013). Panduan Guru Profesional Penelitian Tindakan Kelas (PTK) dan Tindakan Sekolah 
(PTS). Yogyakarta: Andi Ofset. Thayyibandhi, T., \& Sudianto, M. (2014). Meningkatkan Hasil Belajar Tema Ekonomi Melalui Model Pembelajaran Kooperatif Tipe Think Pair Share Siswa Kelas III SDN Ngulanan 2 Bojonegoro. PGSD2, 2, 1-10.

Trianto. (2010). Mendesain Model Pembelajaran Inovatif-Progresif. Jakarta: Kencana Prenada Media.
Wardana, L. W., \& Edoh. (2017). Implementation Of Collaborative Learning Model Thinking Pair Share ( TPS ) And Arias To Improve Student Learning Results In Entrepreneurship Subjects. International Journal of Academic Research in Business and Social Sciences, 7(7), 435-444. https:// doi.org/10.6007/IJARBSS/v7$\mathrm{i} 7 / 3112$ 